\title{
Proteolytic Activity of Escherichia coli Oligopeptidase B Against Proline-Rich Antimicrobial Peptides
}

\author{
Maura Mattiuzzo $^{1 \dagger}$, Cristian De Gobba ${ }^{2 \dagger}$, Giulia Runti ${ }^{1}$, Mario Mardirossian ${ }^{1}$, Antonella Bandiera ${ }^{1}$, \\ Renato Gennaro ${ }^{1}$, and Marco Scocchi ${ }^{1 *}$ \\ ${ }^{1}$ Department of Life Sciences, University of Trieste, Via Giorgieri 5, 34127 Trieste, Italy \\ ${ }^{2}$ University of Copenhagen, Faculty of Science, Department of Food Science Rolighedsvej 30, 1958 Frederiksberg C, Denmark
}

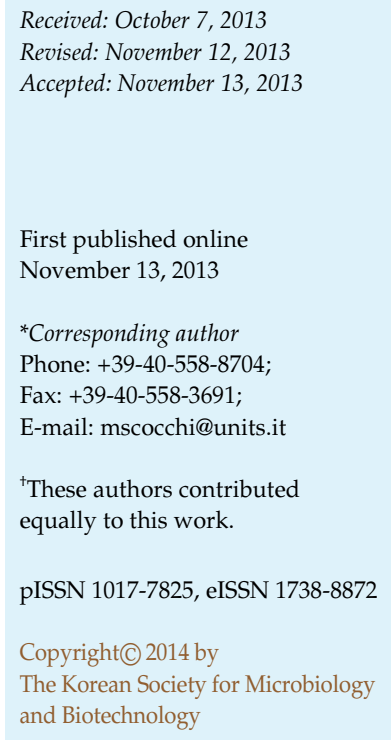

Oligopeptidase B $(\mathrm{OpdB})$ is a serine peptidase widespread among bacteria and protozoa that has emerged as a virulence factor despite its function has not yet been precisely established. By using an OpdB-overexpressing Escherichia coli strain, we found that the overexpressed peptidase makes the bacterial cells specifically less susceptible to several proline-rich antimicrobial peptides known to penetrate into the bacterial cytosol, and that its level of activity directly correlates with the degree of resistance. We established that E. coli OpdB can efficiently hydrolyze in vitro cationic antimicrobial peptides up to 30 residues in length, even though they contained several prolines, shortening them to inactive fragments. Two consecutive basic residues are a preferred cleavage site for the peptidase. In the case of a single basic residue, there is no cleavage if proline residues are present in the $\mathrm{P}_{1}$ and $\mathrm{P}_{2}$ positions. These results also indicate that cytosolic peptidases may cause resistance to antimicrobial peptides that have an intracellular mechanism of action, such as the proline-rich peptides, and may contribute to define the substrate specificity of the E. coli OpdB.

Keywords: Antimicrobial peptide, proline-rich, oligopeptidase B, proteolysis

\section{Introduction}

Oligopeptidase B (OpdB, E.C. 3.4.21.83) is a proteolytic enzyme that belongs to the prolyl oligopeptidase family (POP) of serine proteases $[10,24]$. Initially discovered in E. coli, this enzyme was found in several gram-negative bacteria, spirochetes, $[6,24]$, and protozoa $[5,14]$, but not in higher eukaryotes, with the exception of some plants [6]. Although the physiological role of OpdB has not yet been elucidated in bacteria, it has been recently recognized as an important virulence factor in trypanosome infections [17, 18]. In particular, in infective forms of Trypanosoma cruzi, OpdB generates a calcium signalling factor that interacts with a receptor at the mammalian cell surface, triggering the intracellular mobilization of $\mathrm{Ca}^{2+}$ [4], an essential step for the trypanosome invasion. Deletion of the opdB gene in T. cruzi resulted in trypanosomes that were attenuated for virulence in a mouse model of infection [5]. In Trypanosoma brucei and Trypanosoma congolense, OpdB contributes to the pathogenesis of the infection through the anomalous degradation of biologically active peptides in the bloodstream of infected hosts [31]. Consistent with this view, the administration of irreversible OpdB inhibitors to trypanosomeinfected mice significantly impaired disease progression [19]. These results point out an important role of OpdB in the pathogenesis of parasitic diseases, and its potential as a novel target for antimicrobial therapy prompted an analysis of OpdB homologs in bacteria. Little is known about oligopeptidase $B$ function in bacteria and no physiological substrates have been identified [6]. It has been previously observed that the OpdB from E. coli and Salmonella Typhimurium have a trypsin-like substrate specificity, cleaving peptides after basic residues of arginine and lysine $[15,16]$, and its hydrolytic activity is restricted to peptides shorter than 30-40 residues [7].

In a previous work, OpdB was associated with resistance of E. coli cells to certain antimicrobial peptides (AMPs) [13]. These are an integral part of the innate immune system that 
protect a host from invading pathogenic bacteria [20, 32]. AMPs are considered promising compounds for an alternative use in antibiotic therapy, and hence great effort is being done to understand their mechanism of action [12, 26]. AMPs generally act on the surface of the target cells and are membrane-permeabilizing agents. However, some of them penetrate into the cytoplasm and inhibit intracellular functions [3]. In a previous work, aimed to understand the mode of action of a class of antimicrobial peptides rich in proline residues (PR-AMPs), some E. coli clones showing a reduced susceptibility to the peptides Bac7(1-35) and Bac7(1-16) were isolated [13]. These clones were obtained by transformation of a wild-type strain with a genomic library constructed using DNA from a peptide-resistant mutant. Some plasmids conferring reduced sensitivity to the Bac7 peptides harbored a genomic region containing the opdB gene.

In this study, we investigated the relationship between expression of OpdB and decreased susceptibility of E. coli to proline-rich peptides in order to gain new insights on the activity of OpdB in terms of substrate specificity and mechanism of action. The peptidolytic activity of OpdB on AMPs suggests a possible involvement of this protein in bacterial pathogenicity and, at the same time, it may represent an interesting model to investigate the OpdB substrate specificity.

\section{Materials and Methods}

Peptides, Bacterial Strains, Media, and Growth Conditions

All AMPs used were synthesized, characterized, quantified, and stored as previously described [2]. Bacterial strains and plasmids used in this study are listed in Table 1. Cultures were grown in Luria-Bertani (LB) or Mueller-Hinton (MH) broth at $37^{\circ} \mathrm{C}$ under aerobic conditions with the addition of antibiotics when required.

\section{Antimicrobial Activity Assays}

Determinations of the MIC (Minimum Inhibitory Concentration) values of the AMPs and of the bactericidal activity of Bac7(1-16) against $E$. coli strains were performed as previously described [2]. Significance of differences among groups was performed by the unpaired $t$ test. Values of $p<0.05$ were considered statistically significant.

\section{Oligopeptidase B Cloning and Gene Deletion Constructs}

The pBSAR-1 and pBSAR-11 clones derived from a Bac7resistant mutant DNA library were prepared as previously described [13]. The opdB gene was amplified by PCR from the pBSAR-1 plasmid DNA using forward (5'- CGC AGA TCT ATG CTA CCA AAA GCC GC - $3^{\prime}$ ) and reverse (5'- ACA AGC TTA GTC CGC AGG CGT AGC -3') primers and cloned in the pQE-9 vector. In the resulting plasmid, $\mathrm{PQAC}-1$, the OpdB ORF was fused with a His-tag sequence at the $5^{\prime}$-end, as confirmed by sequencing; this plasmid was then used to transform strain XL-1 Blue of E. coli. The pBSAR-1A, pBSAR-1B, and pBSAR-1C constructs were obtained by cleaving the PBSAR-1 plasmid respectively with BanII, NcoI, and SmaI, whereas the pBSAR-1D and pBSAR-1E constructs were obtained by cutting pBSAR- 1 and pBSAR-11 with BamHI/HindIII.

Expression and Purification of Recombinant Oligopeptidase B

A strain expressing oligopeptidase B (HB3P) was obtained by co-transformation of HB101 with the pQAC-1 and pREP4 plasmids. Mid-logarithmic phase HB3P cultures were incubated in LB broth

Table 1. Strains and plasmid used in this study.

\begin{tabular}{|c|c|c|}
\hline Strain or plasmid & Relevant characteristics or genotype & Reference or source \\
\hline \multicolumn{3}{|l|}{ E. coli strains } \\
\hline HB101 & $\mathrm{F}^{-}$leuB6 proA2 recA13 thi1 ara14 lacY1 galK2 xyl5 mtl1 rpsL20 supE44 hsdS20 lambda- $\mathrm{r}_{\mathrm{B}}^{-} \mathrm{m}_{\mathrm{B}}^{-}$ & DSMZ $^{\mathrm{a}}$ \\
\hline BW25113 & lacl ${ }^{q}$ rrnBT14 DlacZWJ16 hsdR514 DaraBADAH33 DrhaBADLD78 & KEIO collection ${ }^{\mathrm{b}}$ \\
\hline JW1834 & BW25113 $\Delta O p d B, \operatorname{Kan}^{\mathrm{r}}$ & KEIO collection ${ }^{\mathrm{b}}$ \\
\hline \multicolumn{3}{|l|}{ Plasmids } \\
\hline pUC18 & Multicopy vector, $\mathrm{Amp}^{\mathrm{r}}$ & DSMZ $^{\mathrm{a}}$ \\
\hline pQE-9 & Multicopy vector, $\mathrm{Amp}^{\mathrm{r}}$ & Qiagen \\
\hline pQAC1 & pQE-9(OpdB) & This Study \\
\hline pBSAR-1 & pUC18, $\mathrm{Amp}^{\mathrm{r}}, \mathrm{Bac}^{\mathrm{r}}$ & \\
\hline pBSAR-1A & pBSAR-1 $1 \Delta e x o X$ & [13] \\
\hline pBSAR-1B, pBSAR-1C & pBSAR-1 $\triangle O p d B \Delta e x o X$ & This study \\
\hline pBSAR-1D, pBSAR-1E & pBSAR-1 $\triangle O p d B$ & This study \\
\hline
\end{tabular}

${ }^{a}$ DSMZ, German Collection of Microorganisms and Cell Cultures.

${ }^{b}$ Keio Collection at GenoBase (http://ecoli.aist-nara.ac.jp). 
at $30^{\circ} \mathrm{C}$ with $10 \mu \mathrm{M}$ IPTG for different times with shaking. Bacteria were lysed in $6 \mathrm{ml}$ of lysis buffer $(10 \mathrm{mM}$ Tris- $\mathrm{HCl}, \mathrm{pH} 8.0,0.1 \%$ Tween 20), sonicated on ice ( $3 \times 10 \mathrm{sec}$ pulses with $30 \mathrm{sec}$ intervals), centrifuged, and the supernatants stored at $-20^{\circ} \mathrm{C}$. OpdB was purified onto HIS-Select resin $(200 \mu \mathrm{l}$ of $1: 1$ slurry) (SigmaAldrich) in $500 \mathrm{mM} \mathrm{NaCl}, 0.1 \%$ Tween $20,25 \%$ glycerol, and $10 \mathrm{mM}$ Tris- $\mathrm{HCl}, \mathrm{pH} 8.0$ (buffer A), with addition of $5 \mathrm{mM}$ imidazole. After incubation for $30 \mathrm{~min}$ at $4^{\circ} \mathrm{C}$ with shaking, the resin was washed three times first in buffer A supplemented with $20 \mathrm{mM}$ imidazole and then in buffer A with $30 \mathrm{mM}$ imidazole. Finally, the His-tagged-OpdB was eluted with $150 \mathrm{mM}$ imidazole. After estimation of the concentration by the BCA assay (Pierce), the fractions were analyzed by SDS-PAGE and the $12 \%$ acrylamide gels were stained with Coomassie Blue.

\section{Enzymatic Assays}

The OpdB activity of protein extracts was determined by using the fluorogenic substrate carbobenzoxy-Arg-Arg-4-methylcoumaryl 7-amide (Z-Arg-Arg-AMC) [23]. The enzymatic assays were carried out in a reaction mixture of $0.2 \mathrm{ml}$ containing $50 \mu \mathrm{M}$ Z-Arg-ArgAmc in $100 \mathrm{mM}$ Na-phosphate buffer, $\mathrm{pH} 8.0$, and $5 \mu \mathrm{l}$ of soluble protein fraction or $5 \mu \mathrm{l}$ of the purified recombinant endopeptidase. The substrate hydrolysis was monitored at room temperature for 10 min by using a microtiter plate reader (Chameleon Hidex, Finland), set at excitation and emission wavelengths of, respectively, 355 and $460 \mathrm{~nm}$.

\section{Antimicrobial Peptide Degradation}

The peptidolytic activity of recombinant OpdB was evaluated at $37^{\circ} \mathrm{C}$ in $100 \mathrm{mM}$ Na-phosphate buffer, $\mathrm{pH} 8.0$, with a peptide concentration of $100 \mu \mathrm{M}$ and a molar OpdB/peptide ratio of 1:50. Aliquots of the reaction mixture were withdrawn at different times, and the products resolved by RP-HPLC using an analytical X-Terra RPTM C18 column (Waters), eluted with a 0 to $40 \%$ wateracetonitrile linear gradient in the presence of $0.05 \%$ TFA, and monitored at $214 \mathrm{~nm}$. The percentage of cleavage was evaluated from the area of the eluted peaks of the different fragments. Eluted fragments were then identified by ESI-MS using an Esquire 4000 instrument (Bruker Daltonics).

\section{Results}

The Presence of OpdB-Carrying Plasmid in E. coli Confers Reduced Susceptibility to Bac7(1-16)

A plasmid (pBSAR-1) conferring reduced sensitivity to the proline-rich peptide Bac7(1-16) harbored an E. coli genomic region containing the $o p d B$ gene and a partial sequence of the exoX (yobC) gene, coding for oligopeptidase $B(\mathrm{OpdB})$ and exonuclease $X$, respectively [13].

To confirm the involvement of OpdB in the Bac7(1-16) susceptibility, a set of deletion constructs starting from pBSAR-1 were prepared (pBSAR-1A -1E). Only those expressing a complete $o p d B$ coding sequence or with a small deletion of 108 nucleotides at the 3 -end showed a low-susceptibility phenotype and grew on solid medium supplemented with the peptide at $10 \mu \mathrm{M}$. The absence of a complete opdB gene sequence restored the full susceptibility to the peptide, confirming that expression of the $o p d B$ gene was essential to have a low-susceptibility phenotype (Fig. 1).

\section{OpdB Activity Correlates with the Degree of Resistance to Bac7(1-16)}

No mutations were found in the coding region of the opdB gene in pBSAR-1, while the presence of a large $5^{\prime}$ UTR in the plasmid was consistent with the presence of a functional promoter. Therefore, the decreased susceptibility to Bac7 fragments could be due to overexpression of the oligopeptidase B caused by the high copy number of

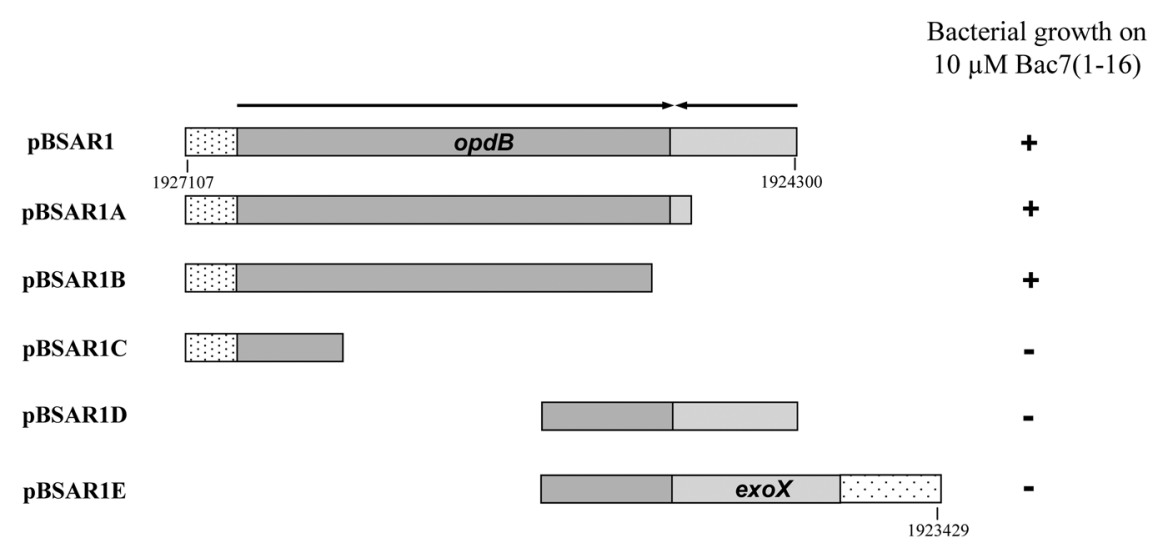

Fig. 1. Schematic representation of the inserts cloned in the plasmid pBSAR-1 and its deletion constructs.

The genomic fragments contained in the plasmid and their ability to confer resistance are schematized. Resistance (+) was considered as capacity of bacteria to grow on a solid medium containing $10 \mu \mathrm{M}$ Bac7(1-16) peptide. Arrows indicate the direction of transcription. 

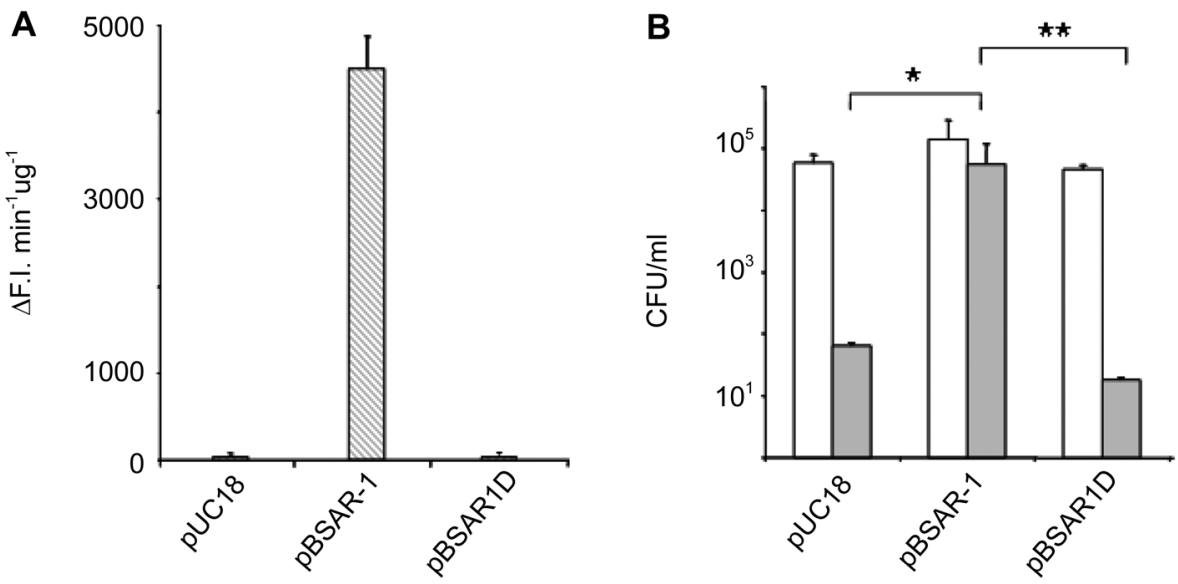

Fig. 2. OpdB activity and susceptibility of E. coli HB101-derived strains to Bac7(1-16).

(A) Hydrolytic activity of OpdB measured in protein bacterial extracts. Soluble fractions of protein extracts from HB101 cells transformed with empty pUC18, pBSAR-1, or pBSAR-1D, were incubated with $50 \mu \mathrm{M}$ Z-Arg-Arg-AMC in $100 \mathrm{mM}$ Na-phosphate buffer, pH 8.0. Enzyme activity was measured as variation in fluorescence intensity (F.I.) $\mathrm{min}^{-1} \mu \mathrm{g}^{-1}$ of protein using a microtiter plate reader settled at excitation and emission wavelengths of, respectively, 355 and $460 \mathrm{~nm}$. (B) Susceptibility of E. coli HB101-derived strains to Bac7(1-16). Bacteria were incubated for 60 min at $37^{\circ} \mathrm{C}$ in $\mathrm{MH}$ broth in the absence (white bars) or presence of $5 \mu \mathrm{M}$ Bac7(1-16) (grey bars), serially diluted with $10 \mathrm{mM} \mathrm{Na}-\mathrm{phosphate}, 400 \mathrm{mM} \mathrm{NaCl}$, and $10 \mathrm{mM} \mathrm{MgCl}_{2}$, $\mathrm{pH}$ 7.4, plated in duplicate on $\mathrm{MH}$ agar, and incubated overnight to allow viable colony counts (CFU/ml). Results are the mean \pm SD of four independent determinations. ${ }^{*} p<0.05$ for HB101/pUC18 vs HB101/pBSAR-1. ${ }^{* *} p<0.05$ for HB101/pBSAR-1D vs HB101/pBSAR-1.

pBSAR-1. To verify this hypothesis, we compared the level of enzymatic activity of OpdB in the protein extracts of different HB101/pBSAR-derived clones with the degree of susceptibility to Bac7(1-16). High levels of OpdB activity, measured using the fluorescent substrate Z-Arg-Arg-AMC, were observed in the HB101/pBSAR-1 protein extract. This activity was due specifically to OpdB since HB101/pBSAR$1 \mathrm{D}$, which contained a partially deleted $o p d B$, showed a very low level of hydrolytic activity (Fig. 2A). In addition, by using the viable plate count method, we found that $E$. coli cells containing pBSAR-1 but not pBSAR-1D showed a remarkably decreased susceptibility to Bac7(1-16) compared with wt HB101/pUC18 (Fig. 2B). In parallel, we evaluated the susceptibility to the proline-rich peptide of an E. coli mutant strain lacking the $\operatorname{opdB}$ gene with respect to its wt counterpart. The viable count assay indicated that the null$o d p B$ JW1834 strain was slightly but significantly more sensitive to the peptide than its parental wild-type BW25113 strain (Fig. 3). Taken together, these results highlight a correlation between the level of expression and activity of OpdB and the bacterial susceptibility to Bac7(1-16), suggesting that this proline-rich peptide may be cleaved in vivo by the peptidase, reducing its antimicrobial activity.

\section{OpdB-Mediated Resistance Can be Extended to Other Proline-Rich Antimicrobial Peptides}

To investigate the specificity of OpdB activity, HB101/

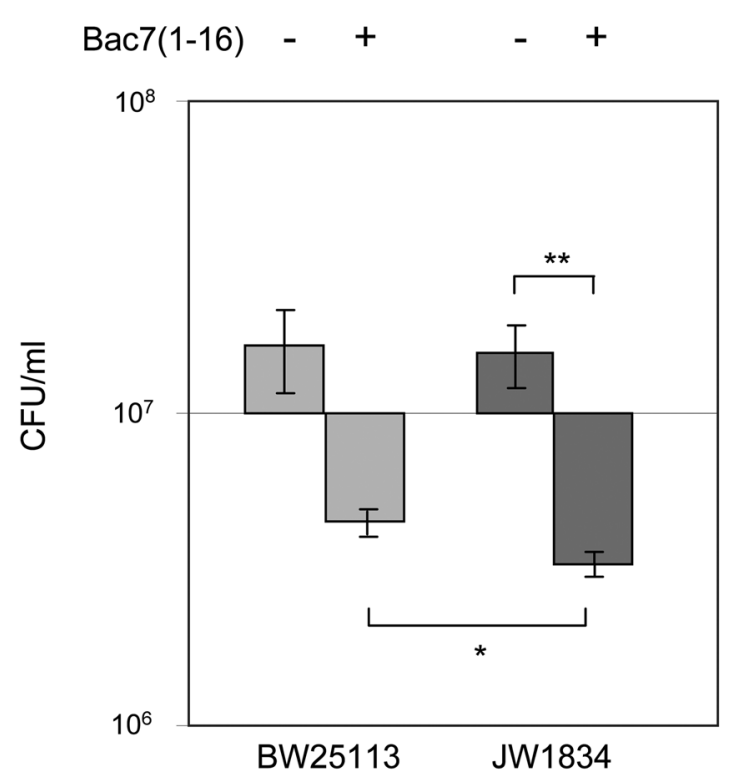

Fig. 3. Susceptibility of E. coli BW25113 and of the opdB-null mutant JW1834 strains to Bac7(1-16).

Bacteria were incubated for $60 \mathrm{~min}$ at $37^{\circ} \mathrm{C}$ in $\mathrm{MH}$ broth with $5 \mu \mathrm{M}$ Bac7(1-16) peptide, serially diluted with $10 \mathrm{mM}$ Na-phosphate, $400 \mathrm{mM} \mathrm{NaCl}$, and $10 \mathrm{mM} \mathrm{MgCl}_{2}$, pH 7.4, plated in duplicate on $\mathrm{MH}$ agar, and incubated overnight to allow viable colony counts (CFU/ml). The results are reported as $\mathrm{CFU} / \mathrm{ml}$ (log scale) and represent the average \pm SD of seven independent experiments. ${ }^{*} p<0.05$ for peptidetreated JW1834 vs peptide-treated BW25113 cells. ${ }^{* *} p<0.01$ for peptidetreated JW1834 vs untreated JW1834 cells. 
Table 2. Susceptibility of the HB101/pBSAR-1 and of the control HB101/pUC18 strains to different AMPs.

\begin{tabular}{ccc}
\hline \multirow{2}{*}{ Peptide } & \multicolumn{2}{c}{ MIC $^{\mathrm{c}}(\mu \mathrm{M})$} \\
\cline { 2 - 3 } & HB101/pUC18 & HB101/pBSAR-1 \\
\hline Bac7(1-35) & 1 & 2 \\
All-D Bac7(1-35) & 16 & 16 \\
Bac7(1-16) & 1 & 4 \\
Bac5(1-31) & 2 & 8 \\
PR39(1-18) & 2 & 16 \\
SMAP-29 & 0.5 & 0.5 \\
\hline
\end{tabular}

'The MIC was taken, after microdilution assay in microtiter plates, as the lowest concentration of antimicrobial peptide resulting in a completely clear well after $18 \mathrm{~h}$ of incubation at $37^{\circ} \mathrm{C}$. Results are the mean values of at least three independent determinations performed in duplicate.

pBSAR-1 cells were exposed to a panel of structurally diverse proline-rich AMPs and to the $\alpha$-helical lytic peptide SMAP-29. The HB101/pBSAR-1 strain showed a remarkably decreased susceptibility, expressed as MIC values, to all the proline-rich AMPs but not to the $\alpha$-helical SMAP-29 (Table 2). In particular, the N-terminal active fragments Bac5(1-31) from the bovine peptide Bac5, and PR-39(1-18) from the porcine PR-39, showed respectively a 4- and 8fold higher MIC value with the OpdB overexpressing strain with respect to the control strain (Table 2). MIC values increased also for the all-L enantiomer of Bac7(1-35) but remained unchanged for the all-D form (Table 2). These results indicate that the overproduction of OpdB can also decrease the bacterial susceptibility towards other prolinerich peptides, suggesting that these AMPs may represent or mimic a specific OpdB substrate recognized by the oligopeptidase in a stereospecific manner.

\section{OpdB Rapidly and Specifically Degrades Proline-Rich} Peptides, Preferring Substrates Shorter than 30 Residues

OpdB was recombinantly expressed and purified (details in Materials and Methods). The expressed product was then incubated with each of the above-mentioned peptides to test their potential as substrates. All the AMPs were hydrolyzed by the enzyme (data not shown), and the cleavage sites were identified by mass spectrometry (Fig. 4). In particular, peptides of less than 30 residues were completely cleaved in small fragments in $20 \mathrm{~min}$ at a 1:50 $\mathrm{OpdB} /$ peptide ratio. On the contrary, peptides longer than 30 residues, such as Bac7(1-35) and Bac5(1-31), were only partially degraded after $60 \mathrm{~min}$ of incubation, leading to a percentage of cleaved molecules of $10 \%$ for Bac7(1-35) and

\section{$\operatorname{Bac7}(1-16) \quad \stackrel{\downarrow}{\text { RRIRPRPPRLPRPRPR }}$}

Bac7(1-35) RRIRPRPPRLPRPRPRPLPFPRPGPRPIPRPLPFP

PR-39(1-18) RRRPRPPYLPRPRPPPFF

Bac5 (1-31) RFRPPIRRPPIRPPFYPPFRPPIRPPIFPPI

\section{SMAP-29 RGLRRLGRKIAHGVKKYGPTVLRIIRIAG}

Fig. 4. Degradation of AMPs by OpdB.

Amino acid sequences of different AMPs and identified cleavage sites for OpdB are reported $(\downarrow)$. Purified recombinant endopeptidase was incubated with each of the AMPs at an enzyme-to-peptide molar ratio of 1:50, and the fragments were obtained after different times (from 20 min to $24 \mathrm{~h}$ ), separated, and identified by LC-MS. The dotted arrows on SMAP-29 represent predicted cleavage sites generating fragments that have not been detected. Underlined PRP sequences represent potential cleavage sites in which the arginine residue is shielded against endopeptidase activity by the two flanking proline residues.

less than 50\% for Bac5(1-31). As expected, all-D-Bac7(1-35) was not cleaved at all (data not shown). As previously reported [6], our data clearly confirm that two consecutive basic residues are a good cleavage site for the peptidase. Moreover, we showed that, in the case of a single basic residue, the cleavage efficiency depends on the presence of proline residues in the positions flanking the cleavage site. When both positions are simultaneously occupied by prolines (PR $\downarrow \mathrm{P}$ ), hydrolysis of the peptide bond after the Arg residue is totally abolished, whereas the presence of a single proline residue in only one of the two flanking positions does not prevent the cleavage (e.g., FR $\downarrow$, PR $\downarrow$ L) (Fig. 4).

\section{Discussion}

Oligopeptidase B is a serine peptidase present in gramnegative bacteria, protozoa, and plants. Despite its widespread distribution, the physiological role of OpdB has not been elucidated yet, even thugh OpdB in Trypanosome and Leishmania infections has been recently recognized as an important virulence factor [14, 18]. Based on enzyme specificity in prokaryotes, it has been suggested that this peptidase may be a processing enzyme that produces biologically active products [23]. Starting from the observation that the presence of an opdB-carrying plasmid in E. coli conferred reduced susceptibility to PR-AMPs, in the present 
work we investigated the activity of this oligopeptidase in the degradation of different antimicrobial peptides. Previous studies have suggested that proline-rich AMPs should be resistant to the action of serine proteases because of the presence of proline residues that prevent cleavage of the scissile bonds [27]. In contrast, our results indicate that the serine peptidase OpdB can degrade proline-rich peptides, broadening the pool of its putative physiologic substrates, whose identity, up to now, is still unknown [6].

Unlike the canonical prolyl oligopeptidases (POP) that catalyze the hydrolysis of the peptide bond on the carboxyl terminal side of proline residues in peptides, OpdB shows a trypsin-like activity $[6,16]$. In particular, it was shown that OpdB of Salmonella enterica exhibits hydrolytic activity exclusively against substrates with basic residues in the $\mathrm{P}_{1}$ position [16]. The present study confirms these results and adds new insights on the specificity of this endopeptidase. We found that the presence of a proline residue in the $\mathrm{P}_{1}$ or $\mathrm{P}_{2}$ position of the substrate peptide does not prevent its cleavage by the enzyme, but when both positions are occupied by proline, no cleavage is observed (Fig. 4). This result suggests a difference in specificity between the prokaryotic and eukaryotic forms of this protein, since the presence of a proline residue in the $\mathrm{P}_{1}$ position of Trypanosome OpdB is sufficient to prevent its activity [9]. Moreover, we showed that E. coli OpdB can efficiently hydrolyze cationic antimicrobial peptides that are less than 30 residues in length, suggesting a size limit of the cleavable unknown peptide substrates.

We showed that the presence of multiple copies of the $o p d B$ gene decreased the susceptibility of the bacteria to Bac7(1-16) and to other proline-rich peptides. A direct correlation between the amount of the peptidase expressed in the cells and the bacterial sensitivity to the PR-AMPs has been shown, indicating an active role of OpdB in conferring the low-susceptibility phenotype to bacteria overexpressing this protein. Interestingly, the endogenous chromosomic OpdB in the wild-type strain also contributed to decreasing the susceptibility of E. coli to Bac7(1-16) with respect to an opdB-null mutant. This indicates that a normal level of oligopeptidase under physiological conditions also displays a protective, albeit modest, effect (Fig. 3).

The production of proteolytic enzymes in response to AMPs has been described in both gram-negative and grampositive bacteria as an important mechanism of resistance towards AMPs $[8,21]$. For example, the outer membrane protease PgtE of Salmonella enterica and of its E.coli homolog OmpT are capable of cleaving $\alpha$-helical AMPs [8] and protamine [29]. P. aeruginosa elastase induces LL-37 degradation in human wound fluid, leading to enhanced bacterial survival [25], and $S$. aureus expresses and secretes the metalloprotease aureolysin and the V8 serine protease, which are also capable of cleaving and inactivating LL-37 [28]. As most of the AMPs act by binding to, and permeabilizing the membranes of target bacteria, up to now only proteases secreted or expressed on the cell surfaces have been shown to be active against AMPs. Here we showed that OpdB confers a reduced susceptibility to proline-rich antimicrobial peptides, which show cellpenetrating capability and act within the target cells [11, 22, $26,30]$. On the other hand, although OpdB is capable of an efficient degradation of the $\alpha$-helical peptide SMAP-29 (Fig. 4), it does not affect its antibacterial activity against living bacteria, most likely because this peptide acts rapidly on the target cells at the membrane level [1] and does not encounter the intracellular peptidase during its bactericidal action.

Based on these data, a role for this peptidase in the resistance of AMPs may only be hypothesized, although the AMPs display features to be good candidates as OpdB substrates, due to their small size and to the presence of several basic residues. Any future evidence indicating that $o p d B$ is upregulated in some conditions will be important to argue that the resistance of the overproducing strains is physiologically meaningful.

However, the selective reduced susceptibility towards the intracellular AMPs due to the proteolytic activity of OpdB indicates that HB101/pBSAR-1 cells may be used also as a powerful tool to investigate the mode of action of AMPs and to discriminate between AMPs that are internalized into the cells from those that act at the membrane level.

In conclusion, the results reported here show for the first time that a cytosolic peptidase can be involved in the degradation of AMPs as well, suggesting a potential and still not fully characterized proteolytic activity towards these molecules. Further studies will be necessary to better characterize the OpdB mechanism of action.

\section{Acknowledgments}

We thank Genobase (Nara Institute of Science and Technology, Japan) for generously providing bacterial strains and plasmids. This work was supported by grants from the Italian Ministry for University and Research (PRIN 2007), and from the Regione Friuli Venezia Giulia (grant under the LR 26/2005, art. 23 for the $\mathrm{R}^{3} \mathrm{~A}^{2}$ Network). 


\section{References}

1. Benincasa $M$, Mattiuzzo $M$, Herasimenka $Y$, Cescutti $P$, Rizzo R, Gennaro R. 2009. Activity of antimicrobial peptides in the presence of polysaccharides produced by pulmonary pathogens. J. Pept. Sci. 15: 595-600.

2. Benincasa M, Scocchi M, Podda E, Skerlavaj B, Dolzani L, Gennaro R. 2004. Antimicrobial activity of Bac7 fragments against drug-resistant clinical isolates. Peptides 25: 2055-2061.

3. Brogden KA. 2005. Antimicrobial peptides: pore formers or metabolic inhibitors in bacteria? Nat. Rev. Microbiol. 3: 238250.

4. Burleigh BA, Caler EV, Webster P, Andrews NW. 1997. A cytosolic serine endopeptidase from Trypanosoma cruzi is required for the generation of $\mathrm{Ca}^{2+}$ signaling in mammalian cells. J. Cell Biol. 136: 609-620.

5. Caler EV, Vaena de Avalos S, Haynes PA, Andrews NW, Burleigh BA. 1998. Oligopeptidase B-dependent signaling mediates host cell invasion by Trypanosoma cruzi. EMBO J. 17: 4975-4986.

6. Coetzer TH, Goldring JP, Huson LE. 2008. Oligopeptidase B: a processing peptidase involved in pathogenesis. Biochimie 90: 336-344.

7. Fulop V, Bocskei Z, Polgar L. 1998. Prolyl oligopeptidase: an unusual beta-propeller domain regulates proteolysis. Cell 94: 161-170.

8. Guina T, Yi EC, Wang H, Hackett M, Miller SI. 2000. A PhoP-regulated outer membrane protease of Salmonella enterica serovar Typhimurium promotes resistance to alphahelical antimicrobial peptides. J. Bacteriol. 182: 4077-4086.

9. Hemerly JP, Oliveira V, Del Nery E, Morty RE, Andrews NW, Juliano MA, Juliano L. 2003. Subsite specificity (S3, S2, $\mathrm{S1}^{\prime}, \mathrm{S2}^{\prime}$, and $\mathrm{S}^{\prime}$ ) of oligopeptidase B from Trypanosoma cruzi and Trypanosoma brucei using fluorescent quenched peptides: comparative study and identification of specific carboxypeptidase activity. Biochem. J. 373: 933-939.

10. Kanatani A, Masuda T, Shimoda T, Misoka F, Lin XS, Yoshimoto T, Tsuru D. 1991. Protease II from Escherichia coli: sequencing and expression of the enzyme gene and characterization of the expressed enzyme. J. Biochem. (Tokyo) 110: 315-320.

11. Kragol G, Lovas S, Varadi G, Condie BA, Hoffmann R, Otvos Jr L. 2001. The antibacterial peptide pyrrhocoricin inhibits the ATPase actions of DnaK and prevents chaperoneassisted protein folding. Biochemistry 40: 3016-3026.

12. Marcos JF, Gandia M. 2009. Antimicrobial peptides: to membranes and beyond. Expert Opin. Drug Discov. 4: 659-671.

13. Mattiuzzo M, Bandiera A, Gennaro R, Benincasa M, Pacor S, Antcheva N, Scocchi M. 2007. Role of the Escherichia coli $\mathrm{SbmA}$ in the antimicrobial activity of proline-rich peptides. Mol. Microbiol. 66: 151-163.

14. McLuskey K, Paterson NG, Bland ND, Isaacs NW, Mottram JC. 2010. Crystal structure of Leishmania major oligopeptidase B gives insight into the enzymatic properties of a trypanosomatid virulence factor. J. Biol. Chem. 285: 39249-39259.

15. Morty RE, Authie E, Troeberg L, Lonsdale-Eccles JD, Coetzer TH. 1999. Purification and characterisation of a trypsin-like serine oligopeptidase from Trypanosoma congolense. Mol. Biochem. Parasitol. 102: 145-155.

16. Morty RE, Fulop V, Andrews NW. 2002. Substrate recognition properties of oligopeptidase B from Salmonella enterica serovar Typhimurium. J. Bacteriol. 184: 3329-3337.

17. Morty RE, Lonsdale-Eccles JD, Morehead J, Caler EV, Mentele R, Auerswald EA, et al. 1999. Oligopeptidase B from Trypanosoma brucei, a new member of an emerging subgroup of serine oligopeptidases. J. Biol. Chem. 274: 2614926156.

18. Morty RE, Pelle R, Vadasz I, Uzcanga GL, Seeger W, Bubis J. 2005. Oligopeptidase B from Trypanosoma evansi. A parasite peptidase that inactivates atrial natriuretic factor in the bloodstream of infected hosts. J. Biol. Chem. 280: 1092510937.

19. Morty RE, Troeberg L, Powers JC, Ono S, Lonsdale-Eccles JD, Coetzer TH. 2000. Characterisation of the antitrypanosomal activity of peptidyl alpha-aminoalkyl phosphonate diphenyl esters. Biochem. Pharmacol. 60: 1497-1504.

20. Nguyen LT, Haney EF, Vogel HJ. 2011. The expanding scope of antimicrobial peptide structures and their modes of action. Trends Biotechnol. 29: 464-472.

21. Peschel A, Sahl HG. 2006. The co-evolution of host cationic antimicrobial peptides and microbial resistance. Nat. Rev. Microbiol. 4: 529-536.

22. Podda E, Benincasa M, Pacor S, Micali F, Mattiuzzo M, Gennaro R, Scocchi M. 2006. Dual mode of action of Bac7, a proline-rich antibacterial peptide. Biochim. Biophys. Acta 1760: 1732-1740.

23. Polgar L. 1997. A potential processing enzyme in prokaryotes: oligopeptidase B, a new type of serine peptidase. Proteins 28: 375-379.

24. Rawlings ND, Polgar L, Barrett AJ. 1991. A new family of serine-type peptidases related to prolyl oligopeptidase. Biochem. J. 279: 907-908.

25. Schmidtchen A, Frick IM, Andersson E, Tapper H, Bjorck L. 2002. Proteinases of common pathogenic bacteria degrade and inactivate the antibacterial peptide LL-37. Mol. Microbiol. 46: 157-168.

26. Scocchi M, Tossi A, Gennaro R. 2011. Proline-rich antimicrobial peptides: converging to a non-lytic mechanism of action. Cell Mol. Life Sci. 68: 2317-2330.

27. Shinnar AE, Butler KL, Park HJ. 2003. Cathelicidin family of antimicrobial peptides: proteolytic processing and protease resistance. Bioorg. Chem. 31: 425-436.

28. Sieprawska-Lupa M, Mydel P, Krawczyk K, Wojcik K, Puklo M, Lupa B, et al. 2004. Degradation of human antimicrobial peptide LL-37 by Staphylococcus aureus-derived proteinases. Antimicrob. Agents Chemother. 48: 4673-4679. 
29. Stumpe S, Schmid R, Stephens DL, Georgiou G, Bakker EP. 1998. Identification of OmpT as the protease that hydrolyzes the antimicrobial peptide protamine before it enters growing cells of Escherichia coli. J. Bacteriol. 180: 4002-4006.

30. Tomasinsig L, Scocchi M, Mettulio R, Zanetti M. 2004. Genome-wide transcriptional profiling of the Escherichia coli response to a proline-rich antimicrobial peptide. Antimicrob. Agents Chemother. 48: 3260-3267.
31. Troeberg L, Pike RN, Morty RE, Berry RK, Coetzer TH, Lonsdale-Eccles JD. 1996. Proteases from Trypanosoma brucei brucei. Purification, characterisation and interactions with host regulatory molecules. Eur. J. Biochem. 238: 728-736.

32. Zasloff M. 2002. Antimicrobial peptides of multicellular organisms. Nature 415: 389-395. 